\title{
Environmental influences on the composition and structure of the freshwater mussels in shallow lakes in the Cuiabá River floodplain
}

\author{
Colle, $A C .^{a}$ and Callil, $C T .^{b *}$ \\ aPrograma de Pós-graduação em Ecologia e Conservação da Biodiversidade, Instituto de Biociências, \\ Universidade Federal de Mato Grosso - UFMT, Av. Fernando Corrêa da Costa, 2367, \\ Boa Esperança, CEP 78060-900, Cuiabá, MT, Brazil \\ bDepartamento de Biologia e Zoologia, Instituto de Biociências, Universidade Federal de Mato Grosso - UFMT, \\ Av. Fernando Corrêa da Costa, 2367, Boa Esperança, CEP 78060-900, Cuiabá, MT, Brazil \\ *e-mail: callil@ufmt.br \\ Received February 16, 2011 - Accepted July 14, 2011 - Distributed May 31, 2012 \\ (With 2 figures)
}

\begin{abstract}
The maintenance of the freshwater mussels' community in lakes is determined by abiotic factors at the local scale and at regional scale by interspecific relations between the larvae of bivalves and fish host. Whereas the distribution pattern at local scale, our goal was to understand the abundance and community composition of bivalves and relate the environmental agents structuring this community. We sampled 20 lakes in the floodplain of the Cuiabá River using a standardized method of sampling. To evaluate the effect of environment on the community we applied multivariate inferential analyses. We found 1.143 individuals alive belonging into six species distributed at the family Hyriidae, Mycetopodidae, Sphaeridae and Corbiculidae. The results showed that in the Pantanal the bivalve assemblage structure is influenced locally by organic matter and particle size, variables that reflect the intense interactions between water-sediment. However it is important to emphasize that these environmental characteristics are the result of the dynamics of this system which is dependent on the flood pulse, a regional factor.
\end{abstract}

Keywords: mussels, species richness, environmental variables, marginal lagoons, Pantanal.

\section{Influências ambientais na composição e estrutura de bivalves em lagoas da planície de inundação do rio Cuiabá}

\begin{abstract}
Resumo
A manutenção da comunidade de bivalves límnicos em lagos é determinada por fatores abióticos em escala local e em escala regional pelas relações interespecíficas entre as larvas do bivalve e o peixe hospedeiro. Considerando o padrão de distiribuição em escala local, nosso objetivo foi conhecer a abundância e a composição da comunidade de bivalves e relacionar os agentes de estruturação desta comunidade. Foram amostrados 20 lagos na planície de inundação do rio Cuiabá usando método padronizado de amostragem. Para avaliar o efeito dos fatores abióticos sobre a comunidade aplicamos análises multivariadas inferenciais. Encontramos 1.143 indivíduos vivos, distribuidos em seis espécies pertencentes às famílias Hyriidae, Mycetopodidae, Sphaeridae e Corbiculidae. Os resultados demonstraram que no Pantanal, a estrutura da assembléia de bivalves é influenciada localmente pela matéria orgânica e granulometria, variáveis que refletem as intensas interações entre água-sedimento. No entanto é importante ressaltar que tais características ambientais são resultantes da dinâmica deste sistema o qual é dependente do pulso de inundação periódico, um fator de escala regional.
\end{abstract}

Palavras-chave: Bivalvia, riqueza de espécies, variáveis ambientais, lagoas marginais, Pantanal.

\section{Introduction}

Undoubtedly, freshwater mussels (Bivalvia, Unionoida) are a key component of aquatic ecosystem (Meador et al., 2011). These large invertebrates can be considered metabolic reactors because they transfer nutrients and energy from water to sediments by filtering, biodeposition of feces and pseudofeces, nutrient mineralization (Spooner and Vaughn, 2006) stimulating the production across trophic levels (Vaughn et al., 2009).

The Unionoida has a complex life cycle in which the larvae are generally temporary parasites of fish (Mansur, 1999; Dillon, 2000). After a period of being encysted in the host tissue, the juveniles descend to the substratum 
and begin the benthic and sedentary phase of their life. This cycle may have major implications in the distribution and abundance of bivalves as their colonization is initially completely dependent on the dispersion of the host fish - a regional process, but their growth and distribution may be determined by local conditions and processes (Vaughn and Taylor, 2000).

The spatial heterogeneity shown by plant and animal assemblages usually has multiple origins (Vaungh et al., 2008). Two classical models are found in the literature (May, 1984): the environmental control model, whereby the environmental variables are considered responsible for the variations observed in the presence and abundance of organisms (Whittaker, 1956; Bray and Curtis, 1957) and the biotic control model, whereby the connections between the organisms, horizontal (competition: Connell, 1983; Schoener, 1983) or vertical (predation: Mech, 1981; Langeland, 1982; Reinertsen et al., 1986), are considered primary factors in structuring assemblages.

Some authors cite the substratum as the variable that explains the abundance and local distribution of bivalves in lotic environments (van der Schalie, 1938; Strayer, 1993; Layzer and Madison, 1995; McRae et al., 2004). Often, the percentages of sand, silt and clay fractions are more efficient explanatory variables than the physical and chemical variables traditionally used by limnologists interested in the distribution of benthic macroinvertebrates (Ward, 1992). From this standpoint, the substratum would be responsible for the availability of habitats and microhabitats (on a scale of individuals), food (directly or absorbed in sediment particles), and protection (e.g., from water currents and predators). The variables of ecological importance in the substratum include the physical structure (granulometric composition), organic content, stability and heterogeneity (Callisto and Esteves, 1996). Factors such as dissolved oxygen, hydrogen potential ( $\mathrm{pH}$ ) (McMahon, 1991), water conductivity and hydroperiod (Maltchik et al., 2010) may also be involved in the distribution of bivalves. The limitation of many bivalves to shallow habitats, when in lentic waters, is related to their low tolerance to hypoxia (Burky, 1983).

Few systems provide the independent replicate sampling required to test what factors underlie mussel's distribution even at a regional level (Krebs et al., 2010). Considering the ecosystem function is a product of the expression of species functional traits and despite the various attributes of freshwater benthic bivalves, little is known about the composition and ecology of this group in Neotropical environments. Therefore, our objectives were: i) to determine the abundance and composition of benthic bivalves in the floodplain of the Cuiabá River, and ii) to identify the factors responsible for the structure of the bivalves' assemblages in these sites. Based on a literature review and the ecological requirements of benthic bivalves, our hypothesis is that the structure of the freshwater mussels in the shallow lakes of the floodplain is generated by the synergistic effect of the organic matter and the size of the particles that make up the sediment.

\section{Material and Methods}

The Pantanal is a large wetland of about $160.000 \mathrm{~km}^{2}$ in the center of the South American continent (Junk and Cunha, 2005). This region is situated in the Upper Paraguay River Basin in the central part of South America between $16^{\circ}$ and $22^{\circ} \mathrm{S}$ latitude and $55^{\circ}$ and $58^{\circ} \mathrm{W}$ longitude, stretching over part of Brazil, Paraguay and Bolivia (Da Silva et al., 2001). Its rich aquatic and terrestrial biota is adapted to the region's characteristic system of drought and flooding (Harris et al., 2005; Junk et al., 2006). For the Pantanal's aquatic environments, generalizations can be made about the dominant role of river waters in determining the seasons of the ecological processes, reflecting on the structure, metabolism and productivity of the systems, as is already recognized for other flood systems (Junk et al., 1989; Neiff, 1990).

The area of this study, located in the northern part of the Mato Grosso Pantanal, encompasses the municipalities of Nossa Senhora do Livramento, Santo Antônio de Leverger, Barão de Melgaço and Poconé. We collected samples from 20 shallow lakes in a floodplain in the River Cuiabá (Figure 1). Scheffer (2004) defines shallow lakes as the environments in which water is frequently mixed and explains the functioning of these systems are determined by intense sediment-water interactions.

The collection of mussels, sediment and comparison of limnological variables occurred simultaneously with the sampling event. Each lake was sampled once during the dry season of 2006 (September-November) and 2007 (June and July) to make it easier to capture the bivalves. The environmental variables considered were: hydrogen potential $(\mathrm{pH})$, electrical conductivity of water $\left(\mu \mathrm{S} . \mathrm{cm}^{-1}\right)$, and dissolved oxygen $(\%)$, which were measured using a YSI 556MPS multiprobe meter, water transparency, measured with a Secchi disk $(\mathrm{cm})$. We collected samples of sediment in triplicate from each lake, using them to determine the granulometric composition and the percentage of organic matter in the sediment (Allen, 1989). To determine the granulometric composition, the samples from sampling points were oven-dried at $60{ }^{\circ} \mathrm{C}$ for 72 hours. Subsamples of the sediment with $200 \mathrm{~g}$ of dry weight were sifted through sieves with $2.0,1.0,0.25,0.125,0.063$, and $<0.063 \mathrm{~mm}$ mesh superimposed in a sieve shaker for 40 minutes. The material retained in each sieve was weighed on analytical scales and the granulometric percentages of the sediment were determined for each mesh size.

Concerning the collection of bivalves to characterize the assemblages, we located mussels when the lakes were low and there were clear waters, but when the lakes were a little deeper and/or had turbid waters, the shells were located by touch (hands and feet) (Gangloff and Feminella, 2007). Once located, they were collected by hand to a maximum depth of $1.60 \mathrm{~m}$. Collection was standardized to 4 hours per collector in each shallow lake. Search time is the most common technique for collecting information about bivalve abundance and is the only technique that can be used to obtain estimates of the total species richness and to locate 


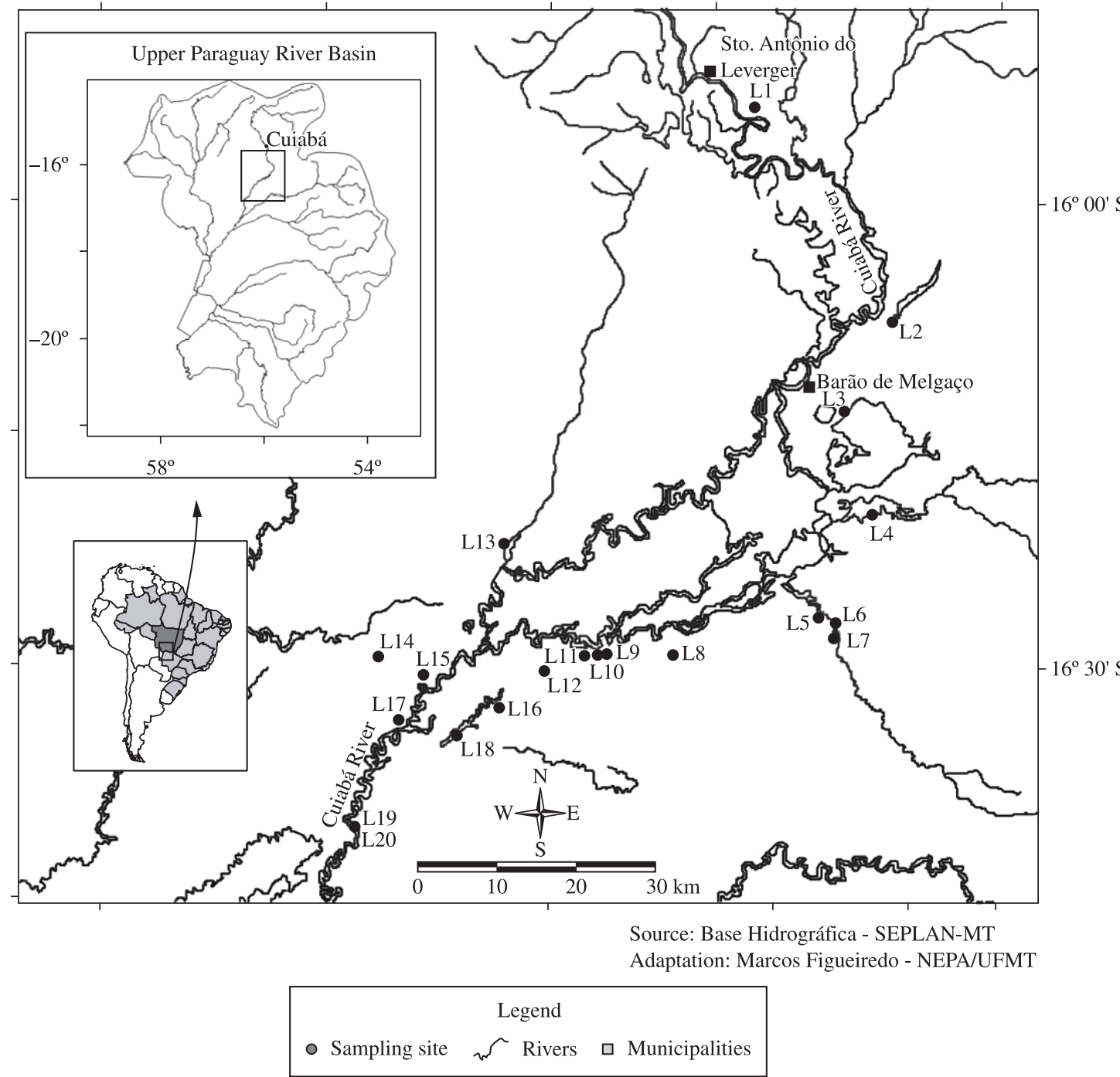

Figure 1. Map of South America, emphasising the Upper Paraguay River Basin in particular, the 20 lakes studied in the floodplain of the Cuiabá River, Pantanal, Brazil. L1 = Poço Lake, L2 = Fazenda Lake, L3 = Chacororé Lake, L4 = Sinhá Mariana Lake, L5 = Pombas Lake, L6 = Conchas Lake II, L7 = São Benedito Lake, L8 = Serragem Lake, L9 = a Barco Velho Lake, L10 = Arraial Lake, L11 = Sardinheira Lake, L12 $=$ Fartura Lake, L13 = Coqueiro Lake, L14 = Meio Lake, L15 = Assoreada Lake, L16 = Embauval Lake, L17 = Corixão Lake, L18 = Moquem Lake, L19 = Conchas Lake I, L20 = Santa Rosa Lake.

rare species (Strayer et al., 1997; Vaughn et al., 1997). We identified all the collected individuals according to the taxonomic level of species. After identifying them, we returned some of the specimens to the environment and deposited a voucher series in the Malacological Collection, José Juan Parodiz-MT at the Biodiversity Center of the Federal University of Mato Grosso (register numbers: JPPMT 536 to 592 and JPPMT 605 to 621).

To reduce the dimensionality of the limnological variables, organic matter and granulometric fractions of the sediment, we applied a Principal Components Analysis (PCA) using the Euclidean distance with the matrix standardized by the standard deviation (SYSTAT version 10.0). The data in this analysis were dissolved oxygen, $\mathrm{pH}$, sediment organic matter, medium sand, fine sand, silt, clay and mud from the 20 sampled shallow lakes. We reduced the dimensionality of the composition of bivalve species by non-metric multidimensional scaling (MDS) using the PC-ORD program (version 4.0). We ordered the composition of the bivalve assemblage based on the species abundances (quantitative ordering) using the Bray-Curtis index as a measure of dissimilarity (Faith et al., 1987) on sample-standardized matrices. We used the axes resulting from the ordering that describe 
Table 1. Richness and abundance of benthic bivalves recorded in 20 lakes perennially sampled between September and November, 2006 and June and July, 2007 in the floodplain of the Cuiaba river, Pantanal, Brazil.

\begin{tabular}{|c|c|c|c|c|c|c|c|c|}
\hline Lakes & 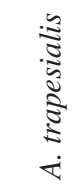 & 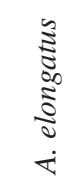 & 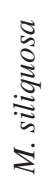 & 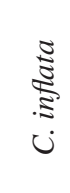 & 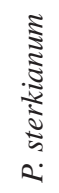 & 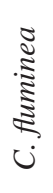 & 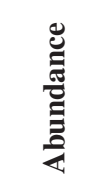 & $\frac{n}{0}$ \\
\hline Coqueiro & 0 & 26 & 3 & 173 & 0 & 0 & 202 & 3 \\
\hline Meio & 80 & 0 & 0 & 0 & 0 & 0 & 80 & 1 \\
\hline Moquém & 0 & 0 & 1 & 36 & 0 & 0 & 37 & 2 \\
\hline Corixão & 0 & 0 & 0 & 40 & 0 & 0 & 40 & 1 \\
\hline Conchas I & 11 & 14 & 0 & 24 & 0 & 0 & 49 & 3 \\
\hline Santa Rosa & 35 & 16 & 0 & 13 & 0 & 0 & 64 & 3 \\
\hline Chacororé & 0 & 20 & 0 & 41 & 0 & 1 & 62 & 3 \\
\hline Poço & 21 & 3 & 0 & 3 & 80 & 0 & 107 & 4 \\
\hline Assoreada & 6 & 3 & 0 & 4 & 0 & 0 & 13 & 3 \\
\hline Fazenda & 22 & 0 & 0 & 0 & 0 & 0 & 22 & 1 \\
\hline Sinhá Mariana & 0 & 0 & 0 & 4 & 0 & 0 & 4 & 1 \\
\hline Conchas II & 6 & 27 & 0 & 3 & 0 & 0 & 36 & 3 \\
\hline Pombas & 0 & 2 & 0 & 95 & 0 & 0 & 97 & 2 \\
\hline Embauval & 7 & 14 & 0 & 8 & 0 & 0 & 29 & 3 \\
\hline Arraial & 0 & 13 & 0 & 30 & 0 & 0 & 43 & 2 \\
\hline Barco Velho & 0 & 16 & 0 & 3 & 0 & 0 & 19 & 2 \\
\hline Sardinheira & 1 & 10 & 0 & 37 & 0 & 0 & 48 & 3 \\
\hline São Benedito & 0 & 0 & 0 & 52 & 0 & 0 & 52 & 1 \\
\hline Fartura & 0 & 28 & 0 & 102 & 0 & 0 & 130 & 2 \\
\hline Serragem & 0 & 2 & 0 & 7 & 0 & 0 & 9 & 3 \\
\hline Total & 189 & 194 & 4 & 675 & 80 & 1 & 1143 & 6 \\
\hline
\end{tabular}

the composition of the community as dependent variables in the inferential test of the effect of the environmental variables. The inferential test was carried out using multivariate multiple regression.

\section{Results}

The lakes around the wetlands of the Cuiabá River are shallow (50-200 cm), and have turbid waters $(20-120 \mathrm{~cm}$ of transparency) and practically neutral (Assoreada lake $\mathrm{pH}=6.7$ ) tending to slightly alkaline (Serragem lake $\mathrm{pH}=8.1$ ) and low electrical conductivity (10 to $140 \mu \mathrm{S} . \mathrm{cm}^{-1}$ ). The sediments are predominantly fine and organic. Seventeen out of the twenty lakes sampled have $80 \%$ fine sand, silt and clay in texture.

We found 1143 live bivalves belonging to six species, distributed among four families: Hyriidae - Castalia inflata (Lamarck, 1819), Mycetopodidae - Anodontites elongatus (Swainson, 1823), Anodontites trapesialis (Lamarck, 1819), Mycetopoda siliquosa (Spix, 1827), Sphaeridae - Pisidium sterkianum (Pilsbry, 1897) and the exotic species Corbicula fluminea (Müller, 1774). The three most abundant species, $C$. inflata, A. elongatus and A. trapesialis, corresponded to 59.05, 16.97 and $16.53 \%$, respectively of the live bivalves found in the lakes. These
Table 2. Result of the Principal Components Analysis (PCA) for environmental variables, their loadings and the percentage of variance explained by the first two components in the 20 lakes sampled between September and November, 2006 and June and July, 2007 in the floodplain of the Cuiaba river, Pantanal, Brazil. Bold: variables with loadings $>0.7$.

\begin{tabular}{lcc}
\hline \multicolumn{3}{c}{ Variables auto values } \\
\hline & $\mathbf{1}$ & $\mathbf{2}$ \\
\hline $\mathrm{pH}$ & -0.201 & 0.566 \\
Dissolved oxygen & -0.204 & $\mathbf{0 . 7 1 5}$ \\
Organic matter & $\mathbf{0 . 9 3 0}$ & 0.123 \\
Medium sand & $\mathbf{0 . 8 0 7}$ & 0.220 \\
Fine sand & 0.252 & $\mathbf{0 . 7 2 6}$ \\
Silt & $\mathbf{- 0 . 8 5 9}$ & -0.302 \\
Clay & 0.312 & -0.579 \\
Mud & $\mathbf{0 . 7 2 1}$ & -0.407 \\
\% of variance explained & 37.69 & 25.17 \\
\hline
\end{tabular}

species were also the most frequent ones occurring, respectively, in 90, 70 and $50 \%$ of the lakes (Table 1).

The first two axes of the PCA corresponded to $63 \%$ of the variation in the limnological data (Table 2). The 


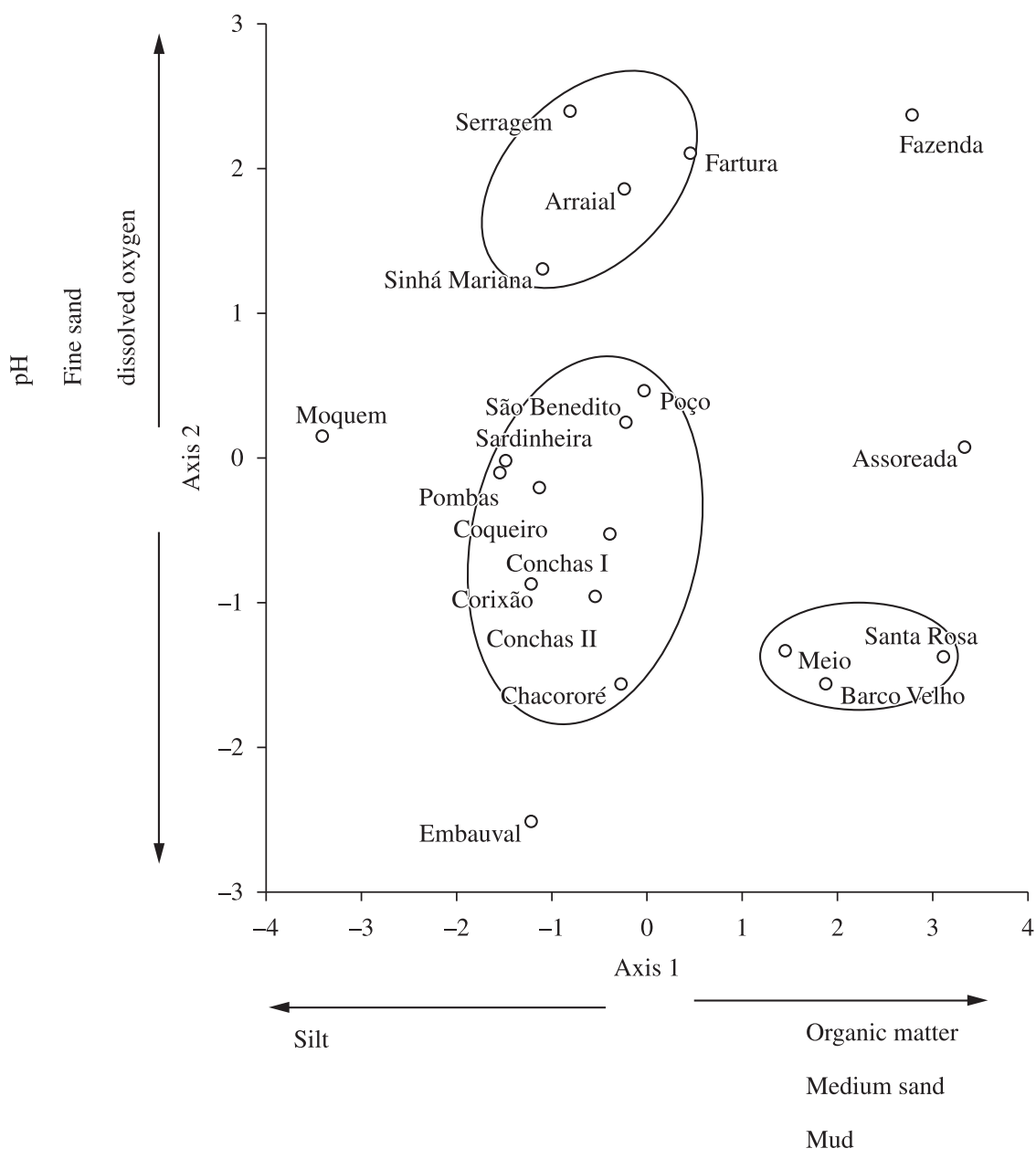

Figure 2. Principal Components Analysis (PCA) linking environmental variables (pH, dissolved oxygen and organic matter, medium sand, fine sand, silt, clay and mud) to 20 ponds which were perennially sampled between September and November, 2006 and June and July, 2007 in the floodplain of the Cuiaba river, Pantanal, Brazil.

first axis explained $38 \%$ of the original variation of the data and was positively related with organic matter, medium sand and mud and negatively related with silt. The second component represented $25 \%$ of the variation in the data. Fine sand and dissolved oxygen were the main variables responsible for the formation of this axis. From this analysis, three distinct groups of environments could be observed (Figure 2). The first and largest group was characterized by the presence of silt and clay in nine of the twenty lakes sampled. Another group was defined by $\mathrm{pH}$, dissolved oxygen and fine sand in the Sinhá Mariana, Serragem, Fartura and Arraial lakes. Organic matter and mud were the main variables that characterize the Santa Rosa, Barco Velho and Baía do Meio lakes. The Embauval, Moquém, Fazenda and Baía Assoreada lakes did not have characteristics common to the groups described.

The composition of the bivalve assemblages was represented by two MDS axes (stress 0.08 ). The multivariate multiple regression indicated that the bivalve assemblages were significantly correlated with organic matter, medium sand, mud and silt (the main variables forming axis 1), represented by the first PCA axis (Pillai Trace $=0.448$, $\left.F_{2,16}=6.486, p=0.009\right)$. However, there was no significant correlation with the variables of fine sand and dissolved oxygen, represented by the second PCA component (Pillai Trace $=0.093, \mathrm{~F}_{2,16}=0.817, \mathrm{p}=0.459$ ).

\section{Discussion}

The richness of six bivalve species recorded for the sampled shallow lakes in the Cuiabá floodplain corresponds to about $20 \%$ of the known richness for lotic environments in this system (M. C. Mansur, pers. comm.). In southern Brazil, Mansur et al. (1991) and Pereira et al. (2000) recorded, respectively, 13 native bivalve species (nine occurring in lakes and 11 in lotic environments) and 19 species, of which only six occurred in lentic environments such as those of the present study. Maltchik et al. (2010) recorded only bivalve's species of the Sphaeriidae for wetlands of this region. 
Our results indicate that the structure of the bivalve assemblages in the lakes of the Cuiabá floodplain was determined by characteristics of the bottom and that there was an interaction between the factors of organic matter and sediment granulometry, which confirms some of the findings reported by other authors (Strayer, 1993; Layzer and Madison, 1995; McRae et al., 2004).

Medium sand and mud showed a positive correlation with the bivalve assemblage in this study, but silt affected the assemblage negatively. Strayer and Ralley (1993) found that the presence of bivalves was related with medium sand $(0.25-1 \mathrm{~mm})$, which is partially congruous with our study, in which a mesh size of $0.25 \mathrm{~mm}$ corresponded to fine sand and $1 \mathrm{~mm}$ mesh to medium size sand grains.

In a study of the bivalves of a temperate lake, Nalepa and Galvin (1988) found greater abundances in sediments consisting of coarse sand and gravel. Salmon and Green (1983) found that bivalves in lotic environments prefer coarse sediments $(>2.0 \mathrm{~mm})$. On the other hand, Mcrae et al., (2004) reported higher bivalve diversity in fine sediments $(<2.0$ to $2.0 \mathrm{~mm})$. Other authors emphasized the importance of the various sediment particle sizes in maintaining the complexity of bivalve assemblages in rivers (Harman, 1972; Holland-Bartels, 1990; Poole and Downing, 2004). Therefore, whereas many species are tolerant to various types of sediments, others occur in specific kinds of sediment (Tevesz and McCall, 1979; Strayer, 1981; Salmon and Green, 1983).

Holland Bartels (1990) stated that the continuous addition of large quantities of fine sediment in the upper Mississippi River may cause a reduction in the current bivalve fauna, especially if it is substituted by fine sediment particles, reducing the diversity of particle sizes. Although bivalve species in general have shown a high tolerance for types of sediment, many of the species studied were statistically less abundant and lower densities were recorded in sites with fine sediment (very fine sand of 75-149 $\mu \mathrm{m}$, silt and mud $<75 \mu \mathrm{m}$ ) than in coarser sediments such as medium and fine sand. Callisto and Esteves (1996) found that the predominance of clay is related with lower abundances of benthic organisms and the presence of only a few groups.

Sediment deposition clog siphons and gills interfere in bivalve feeding and reproduction (Young and Williams, 1983; Dennis, 1984; Aldridge et al., 1987). Junk et al. (2006) claim that one of the threats to the Pantanal is the increase in sediment loads due to erosion. Fine sediments can be more harmful for bivalves in rivers of low gradients than in high gradients, which are more able to remove such particles by water washing (Strayer and Fetterman, 1999).

The shallow lakes grouped by the PCA presented the same granulometric composition, but showed differences in the percentages of sediment fractions. These differences may be essential in maintaining the diversity observed here since the species found presented different body sizes and life cycles. In the Mississippi River, sediments consisting of sand and gravel from areas adjacent to the main channel support almost doubled the density of bivalves than other lentic areas consisting of silt or homogeneous sands from the main channel (Duncan and Thiel, 1983).

The Serragem, Sinhá Mariana, Fartura and Arraial lakes formed a group in the PCA, probably because they presented the highest fractions of fine sand. $C$. inflata was common to all these lakes, which is compatible with Mansur and Valer (1992), who also recorded this species' preference for sandy sediments. On the other hand, in lakes where the presence of A. trapesialis was recorded, no individuals of C. inflata were found, or its abundance, by comparison, was low. Mansur and Valer (1992) and Pereira et al. (2000) found the species of the genus Anodontites to occupy clay or sludgy sediment. In the present study, A. trapesialis did not occur in lakes presenting predominantly sandy sediment, confirming the observations above.

Particulate organic matter is the main food of bivalves (Frissell et al., 1986; Ligon et al., 1995) and influences the structure of the bivalve assemblages of our study. By means of simple regression, we found a positive correlation between A. trapesialis and sediment organic matter $(\mathrm{p}=0.017)$, so that higher abundances of this species were associated with higher percentages of organic matter. Spooner and Vaughn (2006) found that sediment organic matter was significantly higher in treatments with live bivalves (biologically active) than in treatments with biologically inactive shells or sediment.

These findings corroborate our hypothesis that the structure of the bivalve assemblage, in shallow lakes of the Cuiabá River floodplain is determined by two important substratum variables: organic matter and sediment granulometry. However, the factors analyzed here interact in determining the structure of the assemblage

Acknowledgements - The National Council for Scientific and Technological Development $(\mathrm{CNPq})$ process number 132194/2006-6 and the FAPEMAT for the financial support. We also thank Dr. Maria Cristina Mansur and. Dr. Karl Matthias Wantzen for reading this paper and offering suggestions and to Chico Enésio, Vera Uhde and all lab colleagues to help in a field.

\section{References}

ALDRIDGE, DW., PAYNE, BS. and MILLER, AC., 1987. The effects of intermittent exposure to suspended solids and turbulence on three species of freshwater mussels. Environmental Pollution (Serie B), vol. 45, p. 17-28. http://dx.doi.org/10.1016/02697491(87)90013-3

ALLEN, SE., 1989. Chemical analysis of ecological materials. 2nd ed. London: Blackwell Scientific Publications. 368 p.

BRAY, RJ. and CURTIS, JT., 1957. An ordination of the upland forest communities of southern Wisconsin. Ecological Monographs, vol. 27, p. 325-349. http://dx.doi.org/10.2307/1942268

BURKY, AJ., 1983. Physiological ecology of freshwatwe bivalves. In RUSSEL-HUNTER, WD. (Ed.)., The Mollusca Ecology. New York: Academic Press., vol. 6, p. 281-327.

CAllisto, M. and ESTEVES, FA., 1996. Composição granulométrica do sedimento de um lago amazônico impactado 
por rejeito de bauxita e um lago natural (Pará, Brasil). Acta Limnológica, vol. 8, p. 115-126.

CONNELL, JH., 1983. On the prevalence and relative importance of interspecific competition: evidence from experiments. American Naturalist, vol. 122, p. 661- 697. http://dx.doi.org/10.1086/284165

DA SILVA, CJ., WANTZEN, KM., NUNES DA CUNHA, C. and MACHADO, FA., 2001. Biodiversity in the Pantanal Wetland, Brazil. In GOPAL, B., JUNK, WJ. and DAVIS, JA. (Ed.). Biodiversity in wetland: Assessment function and conservation. Leiden: Backhuys Publishers. p. 187-217.

DENNIS, SD., 1984. Distributional analysis of the freshwater fauna of the Tennessee River system, with special reference to the possible limiting effects of siltation. In Virginia Polytechnic Institute and State University. p. 171.

DILLON, RT., 2000. The Ecology of Freshwater Molluscs. Cambridge: Cambridge University Press. 509 p.

DUNCAN, RE. and THIEL, PA., 1983. A survey of the mussel densities in Pool 10 of the upper Mississippi River. Technical Bulletin, Wisconsin Department of Natural Resources Madison, Wisconsin, no. 139. 14 p.

FAITH, DP., MINCHIN, PR. and BELBIN, L., 1987. Compositional dissimilarity as a robust measure of ecological distance. Vegetatio, vol. 69 , p. 57-68.

FRISSELL, CA., LISS, WJ., WARREN, CJ. and HURLEY, MD., 1986. A hierarchical framework for stream habitat classification: viewing streams in a watershed context. Environmental Management, vol. 10, p. 199-214. http://dx.doi.org/10.1007/BF01867358

GANGLOFF, MM. and FEMINELLA, JW., 2007. Stream channel geomorphology influences mussel abundance in southern Appalachian streams, U.S.A. Freshwater Biology, vol. 52, p. 64-74. http://dx.doi.org/10.1111/j.1365-2427.2006.01673.x

HARMAN, WN., 1972. Benthic substrates: their effect on fresh-water Mollusca. Ecology, vol. 53, p. 271-277. http://dx.doi. org/10.2307/1934081

HARRIS, MB., TOMAS, W., MOURÃO, G., SILVA, CJ., GUIMARÃES, E., SONODA, F. and FACHIM, E., 2005. Safeguarding the Pantanal wetlands: Threats and conservation initiatives. Conservation Biology, vol. 19, no. 3, p. 714-720. http://dx.doi.org/10.1111/j.1523-1739.2005.00708.x

HOLLAND-BARTELS, LE., 1990. Physical factors and their influences on the mussel fauna of a main channel border habitat of the upper Mississippi River. Journal of the North American Benthological Society, vol. 9, p. 327-335. http://dx.doi.org/10.2307/1467900

JUNK, W., BAYLEY, PB. and SPARKS, RG., 1989. The flood pulse concept in river floodplain system. Canadian Special Publication of Fisheries and Aquatic Science, vol. 106, p. 110-127.

JUNK, WJ. and CUNHA, CN., 2005. Pantanal: a large South American wetland at a crossroads. Ecological Engineering, vol. 24, p. 391-401. http://dx.doi.org/10.1016/j.ecoleng.2004.11.012

JUNK, WJ., CUNHA, NC., WANTZEN, KM., MARQUES, MI. and ADIS, J., 2006. Comparative biodiversity value of large wetlands: the Pantanal of Mato Grosso, Brazil. Aquatic Sciences, vol. 68 , p. 278-309.

KREBS, RA., BORDEN, WC., STEINER, ER., LYONS, MS., ZAWISKI, W. and WALTON, BM., 2010. Determinants of mussel diversity in Lake Erie tributaries. Journal of the North American
Benthological Society, vol. 29, no. 2, p. 506-520. http://dx.doi. org/10.1899/09-017.1

LANGELAND, A., 1982. Interactions between zooplankton and fish in a fertilized lake. Holarctic Ecology. vol. 5, p. 273-310.

LAYZER, JB. and MADISON, LM., 1995. Microhabitat use by freshwater mussels and recommendations for determining their in stream flow needs. Regulated Rivers: Research and Management, vol. 10, p. 329-345. http://dx.doi.org/10.1002/rrr.3450100225

LIGON, FK., DIETRICH, WE. and TRASH, WJ., 1995. Downstream ecological effects of dams. BioScience, vol. 45, p. 183-192. http:// dx.doi.org/10.2307/1312557

MALTCHIK, L., STENERT, C., KOTZIAN, CB. and PEREIRA, D., 2010. Responses of freshwater molluscs to environmental factors in Southern Brazil wetlands. Brazilian Journal of Biology, vol. 70, no. 3, p. 473-482. http://dx.doi.org/10.1590/S151969842010005000003

MANSUR, MCD., 1999. Gloquídio de Diplodon martensi (Ihering) (Mollusca, Bivalvia, Hyriidae) e seu ciclo parasitário. Revista Brasileira de Zoologia, vol. 16, no. 2, p. 185-194.

MANSUR, MCD., SCHULZ, C., SILVA, MGO. and CAMPOS-VELHO, NMR., 1991. Moluscos bivalves limnícos da Estação Ecológica do Taim e áreas adjacentes, Rio Grande do Sul, Brasil. Iheringia (Série Zoológica), vol. 71, p. 43-58.

MANSUR, MCD. and VALER, M., 1992. Moluscos bivalves do Rio Uraricoera e Rio Branco, Roraima, Brasil. Amazoniana, vol, 12 , no. 1 , p. 85-100.

MAY, RM., 1984. An overview: real and apparent patterns in community structure. In STRONG, DR., SIMBERLOFF, D., ABELE, LG. and THISTLE, AB. (Eds.). Ecological communities: conceptual issues and the evidence. New Jersey: Princeton University Press. p. 3-16.

McMAHON, RF., 1991. Mollusca: Bivalvia. In THORP, J.H. and COVICH A.P. Ecology and Classification of North American Freshwater Invertebrates. New York: Academic Press. p. 315-390.

McRAE, SE., ALLAN, JD. and BURCH, JB., 2004. Reach and catchment-scale determinants of the distribution of freshwater mussels (Bivalvia: Unionidae) in south-eastern Michigan, U.S.A. Freshwater Biology, vol. 49, p. 127-142. http://dx.doi. org/10.1046/j.1365-2426.2003.01165.x

MEADOR, JR., PETERSON, JT. and WISNIEWSKI, JM., 2011. An evaluation of the factors influencing freshwater mussel capture probability,survival, and temporary emigration in a large lowland river. Journal of the North American Benthological Society, vol. 30, no. 2, p. 507-521. http://dx.doi.org/10.1899/10-105.1

MECH, LD., 1981. A decade of data from a single wolf. Endangered Species Technical Bulletin.

NALEPA, TF. and GAUVIN, JM., 1988. Distribution, abundance and biomass of freshwater mussels (Bivalvia: Unionidae) in Lake St. Clair. Journal of Great Lakes Research Contents, vol. 14, p. 411-419. http://dx.doi.org/10.1016/S0380-1330(88)71574-9

NEIFF, JJ., 1990. Ideas for the ecological interpretation of the Paraná River. Interciencia, vol. 15, no. 6, p. 424-441.

PEREIRA, D., VEITENHEIMER-MENDES, IL., MANSUR, MCD. and SILVA, MCP., 2000. Malacofauna límnica do sistema de irrigação da Microbacia do Arroio Capivara, Triunfo, RS, Brasil. Biociências, vol. 8, no. 1, p. 137-157. 
POOLE, KE. and DOWNING, JA., 2004. Relationship of declining mussel biodiversity to stream-reach and watershed characteristics in an agricultural landscape. Journal of the North American Benthology Society, vol. 23, no. 1, p. 114-125. http:// dx.doi.org/10.1899/0887-3593(2004)023\%3C0114:RODMBT \%3E2.0.CO;2

REINERTSEN, RH., JENSEN, A., LANGENLAND, A. and OLSEN, Y., 1986. Algal competition for phosphorus: the influence of zooplankton and fish. Canadian Journal of Fisheries and Aquatic Science, vol. 43, p. 1135-1141. http://dx.doi.org/10.1139/f86-141

SALMON, A. and GREEN, RH., 1983. Environmental determinants of unionid clam distribution in the Middle Thames River, Ontario. Canadian Journal of Zoology, vol. 61, p. 832-838. http://dx.doi. org/10.1139/z83-109

SCHEFFER, M., 2004. Ecology of Shallow Lakes. Kluwer Academic Press. 357 p. Population and Community Biology Series, no. 22.

SCHOENER, TW., 1983. Field experiments on interspecific competition. American Naturalist, vol. 122, p. 240-285. http:// dx.doi.org/10.1086/284133

SPOONER, DE. and VAUGHN, CC., 2006. Context-dependent effects of freshwater mussels on stream benthic communities. Freshwater Biology, vol. 5, p. 1016-1024.

-, 2009. Species richness and temperature influence mussel biomass: a partitioning approach applied to natural communities. Ecology, vol. 90, no. 3, p. 781-790.

STRAYER, DL., 1981. Notes on the microhabitat of unionid mussels in some Michigan streams. American Midland Naturalist, vol. 106, p. 411-415. http://dx.doi.org/10.2307/2425181

-, 1993. Macrohabitats of freshwater mussels (Bivalvia: Unionacea) in streams of the northern Atlantic Slope. Journal of the North American Benthology Society, vol. 12, p. 236-246. http://dx.doi. org/10.2307/1467458

STRAYER, DL. and RALLEY, J., 1993. Microhabitat use by an assemblage of stream-dwelling unionaceans (Bivalvia), including two rare species of Alasmidonta. Journal of the North American Benthology Society, vol. 12, p. 247-258. http://dx.doi. org/10.2307/1467459

STRAYER, DL., CLAYPOOL, S. and SPRAGUE, SJ., 1997. Assessing unionid populations with quadrats and timed searches. In CUMMINGS, KS., BUCHANAN, AC. and KOCH, LM. Conservation and management of freshwater mussels II: initiatives for the future. Rock Island: Upper Mississippi River Conservation Committee (UMRCC). p.163-169.

STRAYER, DL. and FETTERMAN, AR., 1999. Changes in the distribution of freshwater mussels (Unionidae) in the Upper Susquehanna River Basin, 1955-1965 to 1996-1997. American Midland Naturalist, vol. 142, p. 328-339. http://dx.doi. org/10.1674/0003-0031(1999)142[0328:CITDOF]2.0.CO;2

TEVESZ, MJS. and MCCALL PL., 1979. Evolution of substratum preference in bivalves (Mollusca). Journal of Paleontology, vol. 53, p. 112-120.

VAUGHN, CC. and TAYLOR, CM., 2000. Macroecology of a host-parasite relationship. Ecography, vol. 23, p. 11-20. http:// dx.doi.org/10.1111/j.1600-0587.2000.tb00256.x

VAUGHN, CC., TAYLOR, CM. and EBERHARD, KJ., 1997. Comparison of the effectiveness of timed searches versus quadrat sampling in mussels surveys. In CUMMINGS, KS., BUCHANAN, AC. \& KOCH, LM. (Eds.). Conservation and management of freshwater mussels II: initiatives for the future. Rock Island: Upper Mississippi River Conservation Committee (UMRCC). p. 157-162

VAUNGH, CC., NICHOLS, SJ. and SPOONER, DE., 2008. Community and foodweb ecology of freshwater mussels. Journal North American Benthological Society, vol. 27, no. 2, p. 409-423. http://dx.doi.org/10.1899/07-058.1

VAUNGH, CC., ALLEN, DC., IRMSCHER, P. and MILLER,CJ., 2009. Freshwater mussel ecology: a multifactor approach to distribution and abundance. Journal of the North American Benthological Society, vol. 28, no. 2, p. 515-516. http:// dx.doi.org/10.1899/28.2.BR.515.1

VAN DER SCHALIE, H., 1938. The naiad fauna of the Huron River in southeastern Michigan. Miscelaneous Publications of the University of Michigan Museum of Zoology, vol. 40, p. 1-83.

WARD, JV., 1992. Aquatic insect ecology: 1. Biology and habitat. New York: John Wiley \& Sons. 438 p.

WHITTAKER, RH., 1956. Vegetation of the Great Smoky Mountains. Ecological Monographs, vol. 26, p. 1-80. http:// dx.doi.org/10.2307/1943577

YOUNG, M. and WILLIAMS, J., 1983. The status and conservation of the freshwater pearl mussel Margaritifera margaritifera (Linn) in Great Britain. Biological Conservation, vol. 25, p. 35-52. http:// dx.doi.org/10.1016/0006-3207(83)90029-0 